\title{
RNAi-mediated knockdown of aldehyde dehydrogenase class-1A1 and class-3A1 is specific and reveals that each contributes equally to the resistance against 4-hydroperoxycyclophosphamide
}

Jan S. Moreb • Dagmara Mohuczy • Blanca Ostmark • James R. Zucali

Published online: 30 May 2006

(C) Springer-Verlag 2006

Cancer Chemother Pharmacol (2006)

DOI 10.1007/s00280-006-0233-6

Unfortunately, the spelling of one author's name was incorrect. The correct name should read: Dagmara Mohuczy.

The online version of the original article can be found at http:// dx.doi.org/10.1007/s00280-006-0233-6

J. S. Moreb $(\bowtie) \cdot$ D. Mohuczy · B. Ostmark · J. R. Zucali Department of Medicine, Division of Hematology/Oncology,

University of Florida, College of Medicine,

1600 SW Archer Road, Room R4-220,

PO Box 100277, Gainesville, FL 32610, USA

e-mail: morebjs@medicine.ufl.edu 